\title{
EVALUASI PENERAPAN SISTEM INFORMASI ABSENSI ONLINE DENGAN HOT FIT MODEL
}

\author{
Ratna Kartika Wiyati ${ }^{1)}$ Ni Luh Ayu Kartika Yuniastari Sarja ${ }^{2)}$ \\ Program Studi Sistem Informasi ${ }^{1,2}$ \\ STMIK STIKOM Bali ${ }^{1,2)}$ \\ ratna@stikom-bali.ac.id ${ }^{1)}$, yuni@stikom-bali.ac.id ${ }^{2)}$
}

\begin{abstract}
Attendance is a compulsory activity in lectures. STIKOM Bali uses an online attendance information system to attend student attendance in each teaching and learning process. To find out the success of implementing an information system needs to be evaluated. Evaluation is done so that the organization can find out the impact and benefits of implementing an information system for users such as lecturers and academic and organizational sections. Therefore it is necessary to evaluate the STIKOM Bali online attendance information system. This study evaluates success using the HOT Fit model. The selection of the HOT Fit model is because this model involves important components in the application of the system, namely human, technology and organization. The research methods used in this study are exploration of concepts and observations, analysis of variables and hypotheses, data collection and analysis and conclusions. Based on the results of hypothesis evaluation, eleven hypotheses proved significant. Based on this, it can be concluded that the success rate of the online attendance information system at Bali STIKOM is good. While based on the results of the regression test found the influence of the largest variable is the effect of system quality variables on user satisfaction and service quality on usage with the value of $R$ Square of $62.5 \%$.
\end{abstract}

Keywords: attendance, online attendance information system, HOT Fit model

\begin{abstract}
ABSTRAK
Absensi merupakan kegiatan wajib dalam perkuliahan. STIKOM Bali menggunakan sistem informasi absensi online untuk melakukan presensi kehadiran mahasiswa dalam setiap proses belajar mengajar. Untuk mengetahui keberhasilan penerapan sebuah sistem informasi perlu dilakukan evaluasi. Evaluasi dilakukan agar organisasi dapat mengetahui dampak dan manfaat penerapan sistem informasi baik bagi pengguna seperti dosen dan bagian akademik maupun organisasi. Oleh karena itu perlu dilakukan evaluasi terhadap sistem informasi absensi online STIKOM Bali. Penelitian ini melakukan evaluasi kesuksesan menggunakan model HOT Fit. Pemilihan model HOT Fit dikarenakan model ini melibatkan komponen penting dalam penerapan sistem yaitu human atau pengguna, teknologi dan organisasi Metode penelitian yang digunakan dalam penelitian ini adalah eksplorasi konsep dan observasi, analisis variabel dan hipotesis, pengumpulan dan analisis data serta penarikan kesimpulan. Berdasarkan hasil evaluasi hipotesis, sebelas hipotesis terbukti signifikan. Berdasarkan hal tersebut dapat disimpulkan bahwa tingkat kesuksesan sistem informasi absensi online pada STIKOM Bali baik. Sedangkan berdasarkan hasil uji regresi didapatkan pengaruh variabel terbesar adalah pengaruh variabel kualitas sistem terhadap kepuasan pengguna dan kualitas layanan terhadap penggunaan dengan nilai $\mathrm{R}$ Square sebesar $62,5 \%$.
\end{abstract}

Kata kunci : absensi, sistem informasi absensi online, model HOT Fit

\section{PENDAHULUAN}

Absensi merupakan kegiatan wajib dalam perkuliahan. Kegiatan absensi dalam perguruan tinggi dilakukan dengan berbagai cara baik menggunakan sistem manual ataupun memanfaatkan teknologi informasi. STIKOM Bali menggunakan sistem informasi absensi online untuk melakukan presensi kehadiran mahasiswa dalam setiap proses belajar mengajar. Untuk mengetahui keberasilan penerapan sebuah sistem informasi perlu dilakukan evaluasi. Evaluasi dilakukan agar organisasi dapat mengetahui dampak dan manfaat penerapan sistem informasi baik bagi pengguna seperti dosen dan bagian akademik maupun organisasi. Oleh karena itu perlu dilakukan evaluasi terhadap sistem informasi absensi online STIKOM Bali.

Dalam melakukan evaluasi terhadap penerapan sistem informasi terdapat beberapa metode yang digunakan seperti End User Computing Satisfaction (EUCS), 
Technology Acceptance Model (TAM), Unified theory of Acceptance and Use of Technology (UTAUT), Delone Mclean, Human Organization Technology (HOT) Fit Model dan yang lainnya. Tiap metode memiliki komponen dan karakteristik masingmasing.

Penerapan sistem informasi dalam sebuah organisasi akan melibatkan user atau pengguna sistem tersebut. Selain itu unsur organisasi juga menjadi komponen penting dalam penerapan sistem. Model evaluasi penerapan sistem informasi yang melibatkan human atau pengguna, teknologi dan organisasi adalah Model HOT Fit. Oleh karena itu dalam penelitian ini, evaluasi sistem informasi absensi online menggunakan model HOT FIT. Model HOT Fit sendiri dikembangkan oleh Yusof et al untuk mengevaluasi kesuksesan sistem informasi. Human Organization-Technology (HOT) Fit Model merupakan model yang menempatkan komponen penting dalam sistem informasi yakni manusia (human), organisasi (organization) dan teknologi (technology) dan kesesuaian hubungan di antaranya. Salah satu contoh penelitian yang telah menerapkan Model HOT Fit adalah penelitian yang dilakukan oleh Tamubua, dkk [1] melakukan evaluasi faktor keberhasilan aplikasi pemantauan pelaksanaan program dan kegiatan di lingkungan Kemdikbud. Selain itu Rozanda \& Masriana [2] menggunakan model HOT Fit dalam mengevaluasi penerapan Sistem Informasi Manajemen Kepegawaian (SIMPEG) pada Pengadilan Tata Usaha Negara Pekanbaru.

Dengan mengetahui tingkat kesuksesan sistem informasi online pada STIKOM Bali, pihak organisasi maupun eksekutif manajemen dapat menentukan strategi kedepannya sehingga sistem informasi ini dapat menjadi salah satu keunggulan kompetitif organisasi.

\section{LANDASAN TEORI HOT Fit Model}

Teori HOT Fit dikemukakan oleh Yusof et al pada tahun 2006 di Konferensi Internasional Hawaii Science System ke-39. Teori ini dibuat dari dua model evaluasi untuk sistem informasi, model tersebut adalah D\&M IS Success Model (DeLone dan McLean, 2004) dan IT Organization Fit Model (Morton, 1991). Model ini menempatkan komponen penting dalam sistem informasi yakni Manusia (human), Organisasi dan
Teknologi dan kesesuaian hubungan di antaranya.

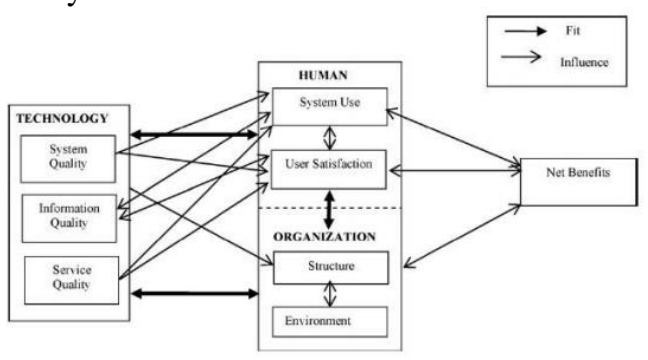

Gambar 1 Human-Organization Technology (HOT) Fit Model

Kerangka teori HOT Fit adalah sebagai berikut :

1. Human

Ada dua hal berikut menjadi komponen penting :

a. System use : mengacu pada keseringan dan cakupan penggunaan fungsifungsi sistem, pelatihan, pengetahuan, pengharapan, dan penerimaan atau penolakan.

b. User Satisfaction : merupakan evaluasi secara keseluruhan dari pengalaman pengguna dalam menggunakan sistem informasi dan potensi pengaruh sistem informasi. User satisfaction berhubungan dengan pengetahuan kedayagunaan sistem dan sikap pengguna tentang sistem informasi yang dipengaruhi karakteristik pengguna

2. Organization

Dua hal berikut menjadi komponen penting :

a. Structure : struktur organisasi mencerminkan keadaan instansi, budaya, politik, hirarki, autonomi, perencanaan dan sistem control, strategi, manajemen, kepemimpinan dan komunikasi.

b. Environment : lingkungan ini adalah lingkungan diluar dari organisasi seperti, politik, kebijakan pemerintah, sumber keuangan (pemilik modal), lokasi, kompetisi, hubungan antar instansi, populasi yang dilayani dan komunikasi.

\section{Technology}

Komponen dalam teknologi tiga hal berikut :

a. System Quality : pengukuran fiturfitur yang terdapat pada sistem informasi terutama kemampuan sistem dan tampilan antar muka. Contoh: ke- 
mudahan penggunaan, kemudahan pembelajaran, waktu tanggapan, kedayagunaan, ketersediaan, tahan uji, penyesuaian, keamanan dan ketersediaan dukungan teknis.

b. Information Quality : berkaitan denan proses informasi dan informasi yang dihasilkan oleh sistem. Kriteria dari kualitas informasi adalah kelengkapan, ketepatan, kemudahan pembacaan, tepat waktu, ketersediaan, relevansi, konsistensi, tahan uji, metode input data, dan kualitas.

c. Service Quality : pengukuran secara keseluruhan dari dukungan penyedia jasa sistem atau teknologi. Kriteria yang diukur adalah kecepatan respons, jaminann layanan, empati dan penanganan layanan.

\section{Net Benefits}

Net Benefits adalah keseimbangan antara dampak positif dan negatif dari pengguna (para pekerja medis, manajer, pegawai non medis, developer sistem dan semua bagian yang terkait). Net Benefit dapat diakses menggunakan benefit langsung, efek pekerjaan, efisiensi dan efektivitas, menurunkan tingkat kesalahan, komunikasi, mengendalikan pengeluaran dan biaya. Semakin tinggi dampak positif yang dihasilkan semakin berhasil implementasi sistem informasi [3].

\section{Penelitian Terkait}

Beberapa penelitian terdahulu yang menggunakan model HOT Fit dan model Delone Mclean adalah sebagai berikut. Penelitian yang dilakukan oleh Krisbiantoro [4] evaluasi keberhasilan implementasi sistem informasi Perpustakaan STMIK AMIKOM Purwokerto dengan pendekatan HOT Fit model. Berdasarkan dari hasil uji untuk melihat variabel yang berpengaruh terhadap keberhasilan implementasi SLiMS di STMIK AMIKOM Purwokerto adalah variabel Teknologi, Manusia dan Organisasi berpengaruh terhadap manfaat atau keberhasilan. Borman [3] melakukan evaluasi penerapan Sistem Informasi Manajemen Kepegawaian (Simpeg) Di Badan Kepegawaian Daerah Kabupaten Pamekasan Dengan Pendekatan Human Organization Technology (HOT) Fit Model. Berdasarkan hasil peneliian penerapan Sitem Infomrasi Manajemen Kepegawaian (SIMPEG) di Badan Kepegawaian Daerah Kabupaten Pamekasan mempunyai tingkat keberhasilan cukup baik, karena berdasarkan hasil klasifikasi tingakatan skor data kuesioner secara umum SIMPEG sudah baik, faktor-faktor keberhasilan yang ada dalam model HOT-Fit dan hubungan antara komponen manusia, organisasi dan teknologi menunjukkan hasil yang baik, meskipun ada beberapa faktor yang perlu ditingkatkan dalam mewujudkan keberhasilan penerapan sistem informasi.

\section{METODOLOGI}

Metodologi penelitian yang digunakan dalam penelitian ini mengadaptasi kerangka berpikir metodologi IS Research yang dikemukakan oleh Hevner pada tahun 2004 [4]. Metodologi penelitian dapat dijelaskan sebagai berikut :

1. Eksplorasi konsep

Pada tahap pertama yaitu eksplorasi konsep yang akan digunakan dalam penelitian yaitu Model HOT Fit dan sistem informasi absensi online yang ada pada STIKOM Bali. Hasil studi literatur dan observasi menghasilkan konsep dan data yang digunakan sebagai dasar dalam analisis.

2. Analisis

Pada tahap analisis dilakukan analisis variabel dan hipotesis dengan menggunakan model HOT Fit. Variabel dan indikator dalam penelitian akan dijadikan dasar dalam penyusunan kuesioner.

3. Pengumpulan dan analisis data Pada tahap pengumpulan data dilakukan penyebaran kuesioner kepada responden dosen. Analisis data pada penelitian ini menggunakan analisis statistik deskriptif dan analisis statistik inferensial. Hasil dari pengumpulan data kuesioner akan diolah dan dianalisis sehingga menghasilkan kesimpulan.

4. Kesimpulan

Tahap terakhir dalam penelitian ini adalah penarikan kesimpulan.

\section{PEMBAHASAN \\ Variabel Penelitian}

Pada penelitian ini terdapat tujuh variabel yang digunakan. Variabel ini diadopsi dari model HOT Fit. Variabel dalam penelitian ini yaitu :

1. Variabel Kualitas Sistem

2. Variabel Kualitas Informasi

3. Variabel Kepuasan Pengguna

4. Variabel Kualitas layanan

5. Variabel Penggunaan sistem

6. Variabel Dampak penggunaan

7. Variabel Organisasi 
Berdasarkan hasil analisis variabel dalam model HOT Fit maka dapat disimpulkan bahwa dalam penelitian ini akan menggunakan tujuh variabel yang diadopsi dan dimodifikasi dari model HOT Fit untuk kesuksesan sistem informasi absensi online pada STIKOM Bali. Model modifikasi HOT Fit dapat dilihat pada Gambar 2.

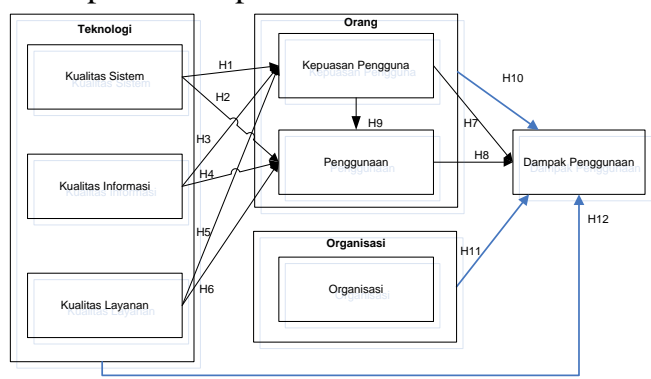

Gambar 2 Model Modifikasi HOT Fit dalam penerapan Sistem Informasi Online

Berdasarkan model penelitian maka dirumuskan hipotesis sebagai berikut :

H1 : Kualitas Sistem (KS) akan berpengaruh terhadap Kepuasan Pengguna (KP).

H2 : Kualitas Sistem (KS) akan berpengaruh terhadap Penggunaan (P).

H3 : Kualitas Informasi (KI) akan berpengaruh terhadap Kepuasan Pengguna (KP).

$\mathrm{H} 4$ : Kualitas Informasi (KI) akan berpengaruh terhadap Penggunaan $(\mathrm{P})$.

H5 : Kualitas Layanan (KL) akan berpengaruh terhadap Kepuasaan Pengguna (KP).

H6 : Kualitas Layanan (KL) akan berpengaruh terhadap Penggunaan $(\mathrm{P})$.

H7 : Kepuasan Pengguna (KP) akan berpengaruh terhadap Dampak Penggunaan (DP).

H8 : Penggunaan (P) akan berpengaruh terhadap Dampak Penggunaan (DP).

H9 : Kepuasan Pengguna (KP) akan berpegaruh terhadap Penggunaan $(\mathrm{P})$.

$\mathrm{H} 10$ : Orang (ON) akan berpengaruh terhadap Dampak Penggunaan (DP).

H11 : Organisasi (OG) akan berpengaruh terhadap Dampak Penggunaan (DP).

H12 : Teknologi (TE) akan berpengaruh terhadap Penggunaan (DP).

Hipotesis H1 sampai H9 merupakan influence, sedangkan H10, H11 dan H12 merupakan hipotesis dari Fit dalam model HOT Fit.

\section{Karakteristik Responden Penelitian}

Responden dalam penelitian ini adalah dosen STIKOM Bali yang merupakan pengguna dari sistem informasi absensi online. Responden penelitian adalah sebanyak 40 orang. Pemilihan sample atau respon- den menggunakan teknik simple random sampling. Karakteristik responden berdasarkan jenis kelamin yaitu sebanyak 22 lakilaki dan 18 perempuan. Karakteristik responden berdasarkan jenis kelamin dapat dilihat pada Gambar 3. Karakteristik responden berdasarkan home base atau program studi (prodi) dosen yaitu 5 orang prodi manajemen informatika, 13 orang prodi sistem komputer dan 22 orang prodi sistem informasi. Karakteristik responden berdasarkan prodi dapat dilihat pada Gambar 4.

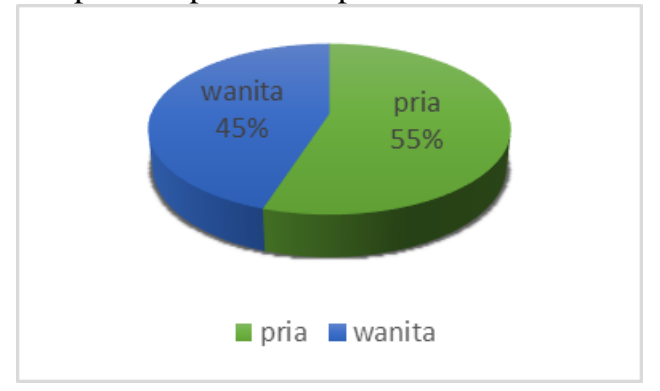

Gambar 3 Karakteristik Responden Berdasarkan Jenis Kelamin

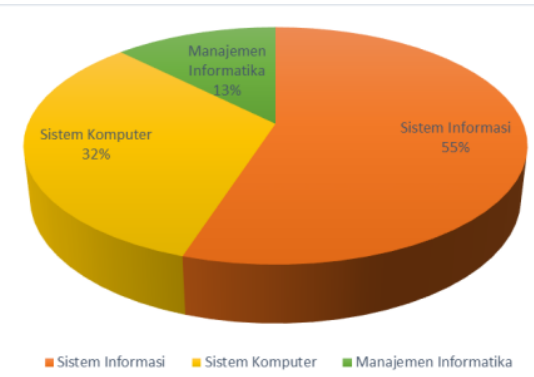

Gambar 4 Karakteristik Responden Berdasarkan Program Studi

Berdasarkan profil dan karakteristik responden dosen, maka dominan dosen yang menjadi responden adalah berjenis kelamin lakilaki yaitu sebanyak 22 dan program studi sistem informasi sebanyak 22 orang.

\section{Uji Validitas dan Uji Reliabilitas}

Uji validitas dalam penelitian ini menggunakan nilai Scale Corrected Item-Total Correlation. R tabel dengan probabilitas 0,05 $(5 \%)$ adalah sebesar 0.2638. Item pertanyaan valid apabila $r$ hitung $>r$ tabel. $R$ hitung untuk masing-masing pertanyaan dapat dilihat pada Tabel 1 .

Tabel 1 Hasil Validitas Kuesioner

\begin{tabular}{|l|l|l|}
\hline & $\begin{array}{l}\text { Corrected Item- } \\
\text { Total Correlation }\end{array}$ & Validitas \\
\hline KS1 & 0,544 & Valid \\
\hline KS2 & 0,454 & Valid \\
\hline KS3 & 0,690 & Valid \\
\hline
\end{tabular}




\begin{tabular}{|l|l|l|}
\hline KS4 & 0,646 & Valid \\
\hline KS5 & 0,457 & Valid \\
\hline KS6 & 0,332 & Valid \\
\hline KS7 & 0,527 & Valid \\
\hline KS8 & 0,576 & Valid \\
\hline KS9 & 0,364 & Valid \\
\hline KS10 & 0,554 & Valid \\
\hline KS11 & 0,657 & Valid \\
\hline KI1 & 0,792 & Valid \\
\hline KI2 & 0,721 & Valid \\
\hline KI3 & 0,698 & Valid \\
\hline KI4 & 0,368 & Valid \\
\hline KI5 & 0,468 & Valid \\
\hline KI6 & 0,583 & Valid \\
\hline KI7 & 0,603 & Valid \\
\hline KP1 & 0,566 & Valid \\
\hline KP2 & 0,548 & Valid \\
\hline KP3 & 0,767 & Valid \\
\hline KL1 & 0,613 & Valid \\
\hline KL2 & 0,509 & Valid \\
\hline KL3 & 0,705 & Valid \\
\hline US1 & 0,792 & Valid \\
\hline US2 & 0,554 & Valid \\
\hline OR1 & 0,126 & Tidak Valid \\
\hline OR2 & 0,374 & Valid \\
\hline OR3 & 0,298 & Valid \\
\hline OR4 & 0,346 & Valid \\
\hline DP1 & 0,487 & Valid \\
\hline DP2 & 0,622 & Valid \\
\hline DP3 & 0,531 & Valid \\
\hline DP4 & 0,432 & Valid \\
\hline DP5 & 0,543 & Valid \\
\hline & & \\
\hline
\end{tabular}

Berdasarkan hasil uji validitas maka item pertanyaan yang tidak valid yaitu OR1 sehingga OR1 tidak diikutkan dalam analisis hipotesis.

Sedangkan untuk pengujian reliabilitas dengan menggunakan nilai Cronbach's Alpha. Nilai tersebut merupakan nilai reliabilitas tes secara keseluruhan. Berdasarkan pada Tabel 4 dapat dilihat nilai Cronbach's Alpha 0,940. Apabila nilai alpha > 0,9 maka reliabilitas tinggi sehingga dapat disimpulkan bahwa seluruh item pertanyaan reliabel

Tabel 2 Reliability Statistics

\begin{tabular}{|r|r|}
\hline Cronbach's Alpha & N of Items \\
\hline, 940 & 35 \\
\hline
\end{tabular}

\section{Pengujian Hipotesis}

Berdasarkan model modifikasi HOT Fit pada Gambar 2, maka dilakukan pengujian hipotesis dengan menggunakan SPSS 20. Data uji yang digunakan sebanyak 40 data berdasarkan hasil penyebaran kuesioner. Pengu- jian dilakukan menggunakan teknik korelasi Kendall-Tau yang merupakan teknik untuk mencari hubungan dan menguji hipotesis antara dua variabel atau lebih, bila datanya berbentuk ordinal [5]. Hasil pengujian hipotesis dapat dilihat pada Tabel 3.

Tabel 3 Hasil Pembuktian Hipotesis

\begin{tabular}{|c|c|c|c|}
\hline \multicolumn{2}{|c|}{ Hipotesis } & \multirow{2}{*}{$\begin{array}{l}\text { Hasil } \\
\text { Pengukuran } \\
\text { Signifikan. } \\
\text { nilai } \\
\text { signifikansi } \\
0.00<0.05 \\
\end{array}$} & \multirow{2}{*}{$\begin{array}{l}\text { Keputusan } \\
\text { Diterima }\end{array}$} \\
\hline 1 & $\mathrm{KS} \rightarrow \mathrm{KP}$ & & \\
\hline 2 & $\mathrm{KS} \rightarrow \mathrm{US}$ & $\begin{array}{l}\text { Signifikan. } \\
\text { nilai } \\
\text { signifikansi } \\
0.00<0.05\end{array}$ & Diterima \\
\hline 3 & $\mathrm{KI} \rightarrow \mathrm{KP}$ & $\begin{array}{l}\text { Signifikan. } \\
\text { nilai } \\
\text { signifikansi } \\
0.00<0.05\end{array}$ & Diterima \\
\hline 4 & $\mathrm{KI} \rightarrow \mathrm{US}$ & $\begin{array}{l}\text { Signifikan. } \\
\text { nilai } \\
\text { signifikansi } \\
0.00<0.05\end{array}$ & Diterima \\
\hline 5 & $\mathrm{KL} \rightarrow \mathrm{KP}$ & $\begin{array}{l}\text { Signifikan. } \\
\text { nilai } \\
\text { signifikansi } \\
0.00<0.05\end{array}$ & Diterima \\
\hline 6 & $\mathrm{KL} \rightarrow \mathrm{US}$ & $\begin{array}{l}\text { Signifikan. } \\
\text { nilai } \\
\text { signifikansi } \\
0.00<0.05\end{array}$ & Diterima \\
\hline 7 & $\mathrm{KP} \rightarrow \mathrm{DP}$ & $\begin{array}{l}\text { Signifikan. } \\
\text { nilai } \\
\text { signifikansi } \\
0.00<0.05\end{array}$ & Diterima \\
\hline 8 & $\mathrm{US} \rightarrow \mathrm{DP}$ & $\begin{array}{l}\text { Signifikan. } \\
\text { nilai } \\
\text { signifikansi } \\
0.00<0.05\end{array}$ & Diterima \\
\hline 9 & $\mathrm{KP} \rightarrow \mathrm{US}$ & $\begin{array}{l}\text { Signifikan. } \\
\text { nilai } \\
\text { signifikansi } \\
0.00<0.05\end{array}$ & Diterima \\
\hline 10 & $\mathrm{OG} \rightarrow \mathrm{DP}$ & $\begin{array}{l}\text { Signifikan. } \\
\text { nilai } \\
\text { signifikansi } \\
0.00<0.05\end{array}$ & Diterima \\
\hline 11 & $\mathrm{OR} \rightarrow \mathrm{DP}$ & $\begin{array}{l}\text { Tidak } \\
\text { Signifikan. } \\
\text { nilai } \\
\text { signifikansi } \\
0.10>0.05\end{array}$ & Ditolak \\
\hline 12 & $\mathrm{TE} \rightarrow \mathrm{DP}$ & $\begin{array}{l}\text { Signifikan. } \\
\text { nilai } \\
\text { signifikansi } \\
0.00<0.05\end{array}$ & Diterima \\
\hline
\end{tabular}

Berdasarkan hasil pengujian hipotesis hampir semua hipotesis diterima dengan 
jumlah 11 hipotesis diterima yaitu $\mathrm{H} 1, \mathrm{H} 2$, H3, H4, H5, H6, H7, H8, H9, H10, H12. Sedangkan terdapat satu hipotesis yang tidak terbukti yaitu H11. Analisis pengujian masing-masing hipotesis dapat dijelaskan sebagai berikut :

1. Hipotesis 1 (H1) terbukti signifikan. Berdasarkan hal tersebut dapat disimpulkan bahwa menurut dosen STIKOM Bali dengan kualitas sistem informasi absensi online yang baik mempengaruhi kepuasan dosen dalam menggunakan sistem.

2. Hipotesis 2 (H2) terbukti signifikan. Berdasarkan hal tersebut dapat disimpulkan bahwa menurut dosen STIKOM Bali dengan kualitas sistem informasi absensi online yang baik mempengaruhi penggunaan sistem.

3. Hipotesis 3 (H3) terbukti signifikan. Berdasarkan hal tersebut dapat disimpulkan bahwa menurut dosen STIKOM Bali dengan kualitas dari informasi sistem informasi absensi online mempengaruhi kepuasan dosen dalam menggunakan sistem.

4. Hipotesis 4 (H4) terbukti signifikan. Berdasarkan hal tersebut dapat disimpulkan bahwa menurut dosen STIKOM Bali dengan kualitas dari informasi sistem informasi absensi online mempengaruhi penggunaan sistem.

5. Hipotesis 5 (H5) terbukti signifikan. Berdasarkan hal tersebut dapat disimpulkan bahwa menurut dosen STIKOM Bali dengan kualitas layanan sistem informasi absensi online mempengaruhi kepuasan dosen dalam menggunakan sistem.

6. Hipotesis 6 (H6) terbukti signifikan. Berdasarkan hal tersebut dapat disimpulkan bahwa menurut dosen STIKOM Bali dengan kualitas layanan sistem informasi absensi online mempengaruhi penggunaan sistem.

7. Hipotesis 7 (H7) terbukti signifikan. Berdasarkan hal tersebut dapat disimpulkan bahwa menurut dosen STIKOM Bali kepuasan pengguna sistem informasi absensi online mempengaruhi dampak penggunaan sistem.

8. Hipotesis 8 (H8) terbukti signifikan. Berdasarkan hal tersebut dapat disimpulkan bahwa menurut dosen STIKOM Bali penggunaan sistem informasi absensi online mempengaruhi dampak penggunaan sistem.

9. Hipotesis 9 (H9) terbukti signifikan. Berdasarkan hal tersebut dapat disimpulkan bahwa menurut dosen STIKOM Bali ke- puasan pengguna sistem informasi absensi online mempengaruhi penggunaan sistem tersebut.

10. Hipotesis 10 (H10) terbukti signifikan. Berdasarkan hal tersebut dapat disimpulkan bahwa menurut dosen STIKOM Bali orang atau human mempengaruhi dampak penggunaan sistem.

11. Hipotesis 11 (H11) tidak terbukti signifikan. Berdasarkan hal tersebut dapat disimpulkan bahwa menurut dosen STIKOM Bali organisasi tidak mempengaruhi dampak penggunaan sistem.

12. Hipotesis 12 (H12) terbukti signifikan. Berdasarkan hal tersebut dapat disimpulkan bahwa menurut dosen STIKOM Bali teknologi mempengaruhi dampak penggunaan sistem.

Berdasarkan hasil evaluasi hipotesis, sebelas hipotesis terbukti signifikan. Berdasarkan hal tersebut dapat disimpulkan bahwa tingkat kesuksesan sistem informasi absensi online pada STIKOM Bali baik.

\section{Pengujian Regresi}

Pengujian regresi dilakukan dengan menggunakan uji regresi sederhana pada SPSS. Pengaruh variabel bebas dan terikat dapat dilihat dari nilai Rsquare masing-masing hipotesis.

1. Pengukuran Regresi Kualitas Sistem terhadap Kepuasan Pengguna

Berdasarkan hasil pengukuran, pengaruh variabel bebas kualitas sistem terhadap variabel terikat kepuasan pengguna yaitu nilai R-Square sebesar 0,625 , yang berarti pengaruh variabel kualitas sistem terhadap variabel penggunaan sebesar $62,5 \%$, dan sisanya sebesar $37,5 \%$ dipengaruhi oleh variabel lain.

Tabel 4 Hasil Pengukuran Regresi Kualitas Sistem Terhadap Kepuasan Pengguna

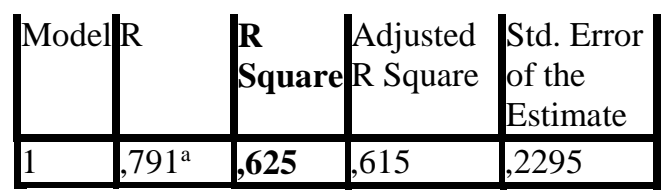

a. Predictors: (Constant), KS

2. Pengukuran Regresi Kualitas Sistem terhadap Penggunaan

Berdasarkan hasil pengukuran, pengaruh variabel bebas kualitas sistem terhadap variabel terikat penggunaan yaitu nilai RSquare sebesar 0,498 , yang berarti pengaruh variabel kualitas sistem terhadap 
variabel penggunaan sebesar $49,8 \%$, dan sisanya sebesar 50,2\% dipengaruhi oleh variabel lain.

Tabel 5 Hasil Pengukuran Regresi Kualitas Sistem Terhadap Penggunaan

\begin{tabular}{|c|c|c|c|c|}
\hline Model & $\mathrm{R}$ & $\begin{array}{l}\text { R } \\
\text { Square }\end{array}$ & $\begin{array}{l}\text { Adjusted } \\
\text { R Square }\end{array}$ & $\begin{array}{l}\text { Std. Error } \\
\text { of the } \\
\text { Estimate }\end{array}$ \\
\hline 1 &, $705^{a}$ &, 498 & 484 &, 3252 \\
\hline
\end{tabular}

a. Predictors: (Constant), KS

3. Pengukuran Regresi Kualitas Informasi terhadap Kepuasan Pengguna

Berdasarkan hasil pengukuran, pengaruh variabel bebas kualitas informasi terhadap variabel terikat kepuasan pengguna yaitu nilai R-Square sebesar 0,457 , yang berarti pengaruh variabel kualitas informasi terhadap variabel kepuasan pengguna sebesar $45,7 \%$, dan sisanya sebesar $54,3 \%$ dipengaruhi oleh variabel lain.

Tabel 6 Hasil pengukuran regresi kualitas sistem terhadap kepuasan pengguna

\begin{tabular}{|l|l|l|l|l|}
\hline Model & $\mathbf{R}$ & $\begin{array}{l}\mathbf{R} \\
\text { Square }\end{array}$ & $\begin{array}{l}\text { Adjusted } \\
\text { R Square }\end{array}$ & $\begin{array}{l}\text { Std. Error } \\
\text { of the } \\
\text { Estimate }\end{array}$ \\
\hline 1 &, $676^{\mathrm{a}}$ & $\mathbf{4 5 7}$ &, 443 &, 2905 \\
\hline
\end{tabular}

a. Predictors: (Constant), KP

4. Pengukuran Regresi Kualitas Informasi terhadap Penggunaan

Berdasarkan hasil pengukuran, pengaruh variabel bebas kualitas informasi terhadap variabel terikat penggunaan yaitu nilai R-Square sebesar 0,524 , yang berarti pengaruh variabel kualitas informasi terhadap variabel penggunaan sebesar 52,4 $\%$, dan sisanya sebesar $47,6 \%$ dipengaruhi oleh variabel lain.

Tabel 7 Hasil pengukuran regresi kualitas informasi terhadap penggunaan

\begin{tabular}{|c|c|c|c|c|}
\hline Model & $\mathrm{R}$ & $\begin{array}{l}\text { R } \\
\text { Square }\end{array}$ & $\begin{array}{l}\text { Adjusted } \\
\text { R Square }\end{array}$ & $\begin{array}{l}\text { Std. Error } \\
\text { of the } \\
\text { Estimate }\end{array}$ \\
\hline 1 & $724^{a}$ &, 524 & 511 &, 2721 \\
\hline
\end{tabular}

a. Predictors: (Constant), US

5. Pengukuran Regresi Kualitas Layanan terhadap Kepuasan Pengguna

Berdasarkan hasil pengukuran, pengaruh variabel bebas kualitas layanan terhadap variabel terikat kepuasan pengguna yaitu nilai R-Square sebesar 0,320, yang berarti pengaruh variabel kualitas layanan terhadap variabel kepuasan pengguna sebesar $32 \%$, dan sisanya sebesar $68 \%$ dipengaruhi oleh variabel lain.

Tabel 8 Hasil Pengukuran Regresi Kualitas Layanan Terhadap Kepuasan Pengguna

\begin{tabular}{|l|l|l|l|l|}
\hline Model & $\mathbf{R}$ & $\begin{array}{l}\mathbf{R} \\
\text { Square }\end{array}$ & $\begin{array}{l}\text { Adjusted } \\
\text { R Square }\end{array}$ & $\begin{array}{l}\text { Std. Error } \\
\text { of the } \\
\text { Estimate }\end{array}$ \\
\hline 1 &, $566^{\mathrm{a}}$ & $\mathbf{3 2 0}$ &, 302 &, 3090 \\
\hline
\end{tabular}

a. Predictors: (Constant), KL

6. Pengukuran Regresi Kualitas Layanan terhadap Penggunaan

Berdasarkan hasil pengukuran, pengaruh variabel bebas kualitas layanan terhadap variabel terikat penggunaan yaitu nilai $R$ Square sebesar 0,625 , yang berarti pengaruh variabel kualitas layanan terhadap variabel penggunaan sebesar $62,5 \%$, dan sisanya sebesar $37,5 \%$ dipengaruhi oleh variabel lain.

Tabel 9 Hasil Pengukuran Regresi Kualitas Layanan Terhadap Penggunaan

\begin{tabular}{|c|c|c|c|c|}
\hline Model & $\mathrm{R}$ & $\begin{array}{l}\text { R } \\
\text { Square }\end{array}$ & $\begin{array}{l}\text { Adjusted } \\
\text { R Square }\end{array}$ & $\begin{array}{l}\text { Std. Error } \\
\text { of the } \\
\text { Estimate }\end{array}$ \\
\hline 1 &, $790^{a}$ &, 625 &, 615 &, 2811 \\
\hline
\end{tabular}

a. Predictors: (Constant), KL

7. Pengukuran Regresi Kepuasan Pengguna terhadap Dampak Penggunaan

Berdasarkan hasil pengukuran, pengaruh variabel bebas kepuasan pengguna terhadap variabel terikat dampak penggunaan yaitu nilai R-Square sebesar 0,473 , yang berarti pengaruh variabel kepuasan pengguna terhadap variabel dampak penggunaan sebesar $47,3 \%$, dan sisanya sebesar 52,7\% dipengaruhi oleh variabel lain.

Tabel 10 Hasil Pengukuran Regresi Kepuasan Pengguna Terhadap Dampak Penggunaan

\begin{tabular}{|l|l|l|l|}
\hline Model R & $\begin{array}{l}\text { R } \\
\text { Square }\end{array}$ & $\begin{array}{l}\text { Adjusted } \\
\text { R Square }\end{array}$ & $\begin{array}{l}\text { Std. Error } \\
\text { of the } \\
\text { Estimate }\end{array}$ \\
\hline
\end{tabular}




\begin{tabular}{|l|l|l|l|l|}
\hline 1 &, $688^{\mathrm{a}}$ & $\mathbf{4 7 3}$ &, 459 &, 2914 \\
\hline
\end{tabular}

a. Predictors: (Constant), KP

8. Pengukuran Regresi Penggunaan Terhadap Dampak Penggunaan

Berdasarkan hasil pengukuran, pengaruh variabel bebas penggunaan terhadap variabel terikat dampak penggunaan yaitu nilai R-Square sebesar 0,432 , yang berarti pengaruh variabel penggunaan terhadap variabel dampak penggunaan sebesar $43,2 \%$, dan sisanya sebesar $56,8 \%$ dipengaruhi oleh variabel lain.

Tabel 11 Hasil Pengukuran Regresi Penggunaan Terhadap Dampak Penggunaan

\begin{tabular}{|l|l|l|l|l|}
\hline Model & $R$ & $\begin{array}{l}\mathbf{R} \\
\text { Square }\end{array}$ & $\begin{array}{l}\text { Adjusted } \\
\text { R Square }\end{array}$ & $\begin{array}{l}\text { Std. Error } \\
\text { of the } \\
\text { Estimate }\end{array}$ \\
\hline 1 &, $657^{\mathrm{a}}$ & $\mathbf{4 3 2}$ &, 417 &, 3026 \\
\hline
\end{tabular}

a. Predictors: (Constant), US

9. Pengukuran Regresi Kepuasan Pengguna Terhadap Penggunaan

Berdasarkan hasil pengukuran, pengaruh variabel bebas kepuasan pengguna terhadap variabel terikat penggunaan yaitu nilai R-Square sebesar 0,517, yang berarti pengaruh variabel kepuasan pengguna terhadap variabel penggunaan sebesar $51,7 \%$, dan sisanya sebesar $48,3 \%$ dipengaruhi oleh variabel lain.

Tabel 12 Hasil Pengukuran Regresi Kepuasan Penggunaan Terhadap Penggunaan

\begin{tabular}{|l|l|l|l|l|}
\hline Model & R & $\begin{array}{l}\text { R } \\
\text { Square }\end{array}$ & $\begin{array}{l}\text { Adjusted } \\
\text { R Square }\end{array}$ & $\begin{array}{l}\text { Std. Error } \\
\text { of the } \\
\text { Estimate }\end{array}$ \\
\hline 1 &, $719^{\mathrm{a}}$ & $\mathbf{5 1 7}$ &, 505 &, 3187 \\
\hline
\end{tabular}

a. Predictors: (Constant), KP

10. Pengukuran Regresi Organisasi Terhadap Dampak Penggunaan

Berdasarkan hasil pengukuran, pengaruh variabel bebas organisasi terhadap variabel terikat dampak penggunaan yaitu nilai R-Square sebesar 0,162, yang berarti pengaruh variabel organisasi terhadap variabel dampak penggunaan sebesar $16,2 \%$, dan sisanya sebesar $83,8 \%$ dipengaruhi oleh variabel lain.
Tabel 13 Hasil Pengukuran Regresi Organisasi Terhadap Dampak Penggunaan

\begin{tabular}{|c|c|c|c|c|}
\hline Model & $\mathrm{R}$ & $\begin{array}{l}\text { R } \\
\text { Square }\end{array}$ & $\begin{array}{l}\text { Adjusted } \\
\text { R Square }\end{array}$ & $\begin{array}{l}\text { Std. Error } \\
\text { of the } \\
\text { Estimate }\end{array}$ \\
\hline 1 &, $403^{a}$ &, 162 &, 140 & ,3674 \\
\hline
\end{tabular}

a. Predictors: (Constant), OR

11. Pengukuran Regresi Orang Terhadap Dampak Penggunaan

Berdasarkan hasil pengukuran, pengaruh variabel bebas orang terhadap variabel terikat dampak penggunaan yaitu nilai R-Square sebesar 0,537, yang berarti pengaruh variabel orang terhadap variabel dampak penggunaan sebesar $53,7 \%$, dan sisanya sebesar $46,3 \%$ dipengaruhi oleh variabel lain.

Tabel 14 Hasil Pengukuran Regresi Orang Terhadap Dampak Penggunaan

\begin{tabular}{|l|l|l|l|l|}
\hline Model & $R$ & $\begin{array}{l}\text { R } \\
\text { Square }\end{array}$ & $\begin{array}{l}\text { Adjusted } \\
\text { R Square }\end{array}$ & $\begin{array}{l}\text { Std. Error } \\
\text { of the } \\
\text { Estimate }\end{array}$ \\
\hline 1 &, $733^{\mathrm{a}}$ & $\mathbf{5 3 7}$ &, 525 &, 2732 \\
\hline
\end{tabular}

a. Predictors: (Constant), OG

12. Pengukuran Regresi Teknologi Terha dap Dampak Penggunaan

Berdasarkan hasil pengukuran, pengauh variabel bebas teknologi terhadap variabel terikat dampak penggunaan yaitu nilai R-Square sebesar 0,513, yang berarti pengaruh variabel teknologi terhadap variabel dampak penggunaan sebesar 51,3\%, dan sisanya sebesar $48,7 \%$ dipengaruhi oleh variabel lain.

Tabel 15 Hasil Pengukuran Regresi Teknologi Terhadap Dampak Penggunaan

\begin{tabular}{|l|l|l|l|l|}
\hline Model & $R$ & $\begin{array}{l}\text { R } \\
\text { Square }\end{array}$ & $\begin{array}{l}\text { Adjusted } \\
\text { R Square }\end{array}$ & $\begin{array}{l}\text { Std. Error } \\
\text { of the } \\
\text { Estimate }\end{array}$ \\
\hline 1 &, $716^{\mathrm{a}}$ &, 513 &, 500 &, 2801 \\
\hline
\end{tabular}

a. Predictors: (Constant), TE 


\section{SIMPULAN}

Setelah dilakukan pengujian korelasi dan regresi terhadap variabel antara kualitas informasi, kualitas sistem, kualitas layan-an, kepuasan pelanggan, penggunaan dan dampak penggunaan terbukti bahwa ada-nya hubungan dan pengaruh yang kuat antar variabel. Pengujian hipotesis dengan metode korelasi didapatkan bah-wa terdapat sebelas hipotesis yaitu H1, H2, H3, H4, H5, H6, H7, H8, H9, H10, H12 terbukti. Berdasarkan hal tersebut maka dapat disimpulkan bahwa berdasar-kan hasil evaluasi dengan model HOT Fit, tingkat kesuksesan sistem informasi absensi online adalah baik. Pengaruh variabel terbesar adalah penga-ruh variabel Kualitas Sistem terhadap Kepuasan Pengguna dan Kualitas Layan-an terhadap Penggunaan dengan nilai R Square sebesar $62,5 \%$. Dan pengaruh variabel terkecil adalah pengaruh vari-abel organisasi terhadap dampak peng-gunaan dengan nilai R Square sebesar 16,2\%.

\section{DAFTAR PUSTAKA}

[1] Tammubua, Y., Sodjiono,B., Sofyan, A.F. (2015). Evaluasi Faktor Keberhasilan Aplikasi Pemantauan Pelaksanaan Program Dan Kegiatan (studi kasus : BPSDMPK-PMP Kemdikbud RI). Seminar Nasional Teknologi Informasi dan Multimedia 2015. Yogyakarta, 1.2-349 1.2-354

[2] Rozanda, N.E., Masriana, A.(2017). Perbandingan Metode Hot Fit dan Tam dalam Mengevaluasi Penerapan Sistem Informasi Manajemen Kepegawaian (SIMPEG) (Studi Kasus : Pengadilan Tata Usaha Negara Pekanbaru). Seminar Nasional Teknologi Informasi, Komunikasi dan Industri (SNTIKI). Riau, 327-336

[3] Borman, R.I., Rosidi, A., Arief, M.R. (2012). Evaluasi Penerapan Sistem Informasi Manajemen Kepegawaian (SIMPEG) Di Badan Kepegawaian Daerah Kabupaten Pamekasan Dengan Pendekatan Human Organization Technology (HOT) Fit Model. Jurnal Teknologi Informasi. VII (20), 1-18.

[4] Krisbiantoro, D., Suyanto, M., Luthfi, E.T. (2015). Evaluasi Keberhasilan Implementasi Sistem Informasi Dengan Pendekatan HOT Fit Model (Studi Kasus : Perpustakaan STMIK AMIKOM Purwokerto). Konferensi Nasional Sistem \& Informatika 2015. Denpasar, 896-901.

[5] A. C. Hevner, et al. "Design Science in Information Systems Research, Management", Information Systems Quarterly, vol 28(1). 2004, 77-105

[6] Sugiyono. Metode Penelitian Bisnis, Bandung: alfabeta, 2008. 